\title{
Twórczość codzienna jako zasób wspierający dobrostan ludzi
}

\begin{abstract}
Twórczość codzienna to jest postawa. Czerpiąc ze swych zasobów, talentów, robi się coś, co jest nowe dla siebie, a nie w ogóle. Przekracza się utarte schematy. Zestawia się na nowo i to daje osobisty wymiar naszemu życiu.

„Poszukiwaczka”"

Myślę, że wszelka narracja, nawet jeśli opowiada o fakcie najbardziej zwyczajnym, kontynuuje tradycje wielkich historii opowiadanych w mitach [...]. Myślę, że zainteresowanie narracją, opowieścią jest elementem naszej ludzkiej kondycji [...]. Nasze istnienie nie jest istnieniem nieruchomych kamieni, kwiatów czy owadów, których rzeczy toczą się ściśle wyznaczonym torem. Nasze istnienie jest przygodą. Człowiek nigdy nie przestanie słuchać opowieści.
\end{abstract}

Eliade, 1992

\section{Wstęp}

Prezentowany poniżej rozdział składa się z dwóch części. Dla moich rozważań podstawową perspektywą odniesienia jest pedagogika twórczości, dlatego w pierwszej części rozdziału omawiam pokrótce wybrany, egalitarny nurt badań i refleksji nad twórczością, szerzej opisany we wcześniejszych publikacjach (m.in. Szmidt, 2002, 2007; Świgulska, 2007, 2009). W drugiej części rozdziału odwołuję się do własnych badań biograficzno-narracyjnych nad twórczością codzienną. Perspektywę pedagogiki twórczości wzbogacam w tym fragmencie wybranymi założeniami

${ }^{1}$ Cytat pochodzi z wypowiedzi osoby biorącej udział w badaniach na rzecz kategorii twórczości codziennej. 
psychologii narracyjnej, a szczególnie koncepcją autonarracji i próbuję odpowiedzieć na pytanie - czy autonarracje mogą być postrzegane jako twórcze zasoby narratorów.

\section{Twórczość egalitarna/codzienna w literaturze przedmiotu}

Współcześnie w psychologii i pedagogice twórczość funkcjonuje jako termin o szerokim znaczeniu, dokonuje się w niej rozróżnienia na twórczość egalitarną i elitarną, bowiem bez tego trudno byłoby psychologom i pedagogom porozumieć się co do sposobu jej definiowania i badania. Twórczość to niewątpliwie wybitne osiągnięcia w nauce, sztuce i wynalazczości, ale również, jak chcą psycholodzy i pedagodzy, wiąże się ona $\mathrm{z}$ aktywnością generującą zachowania oraz wytwory nowe, mające przede wszystkim znaczenie rozwojowe dla działającego podmiotu. Określenia elitarne - egalitarne mogą kojarzyć się z hierarchicznymi podziałami na kulturę „wysoką"/,elitarną” i „niską"/,masową”. Wytwory sytuowane na drugim krańcu twórczości mogą kojarzyć się z pośledniejszą i drugorzędną odmianą tych wartościowanych jako wysokie (Heinich, 2010). Zapewne dlatego w refleksji przedstawicieli nauk społecznych pojawiają się nowe określenia dla twórczości egalitarnej, takie jak twórczość subiektywna, osobista, demokratyczna, codzienna, które mają abstrahować od podziałów przywołujących na myśl działania profesjonalne i nieprofesjonalne, znane i nieznane, a podkreślające przede wszystkim znaczenie działań autokreacyjnych dla kształtowania własnej podmiotowości i tożsamości. Jeżeli wskazuje się bieguny twórczości, to nie w celu deprecjonowania jednego z nich, ale raczej uchwycenia wielości form i różnorodności działań twórczych zarówno w sensie ilościowym, jak i jakościowym. Takie ujęcie wyklucza wąskie, normatywne rozumienie twórczości jedynie jako sfery działań artystycznych i intelektualnych. Z jednej strony mamy rzeczywiście do czynienia $\mathrm{z}$ wyrafinowanymi efektami twórczości, inspirującymi kolejne pokolenia twórców, z drugiej wytwory ulotne, ,nieskrystalizowane”, przejawiające się np. celnym komentarzem, trafnym żartem sytuacyjnym w postaci gry językowej, zaskakującą i smaczną potrawą (np. polską odmianą pizzy z kapustą, grzybami i grochem), zindywidualizowanym stylem bycia, odzwierciedlającym niepowtarzalny sposób postrzegania świata (Szmidt, 2007, 2013; Heinich, 2010).

Źródeł szerokiego postrzegania twórczości, a tym samym kategorii twórczości codziennej można doszukiwać się m.in. w przemianach kulturowych i społecznych lat 60. XX w., które wpłynęły na społeczne postrzeganie codzienności i twórczości. Dzięki kontrkulturze tamtego okresu działania twórcze można wpisać w nowe kody kulturowe i traktować jako sposobność rozwoju w różnych aspektach życia (Czartoryska, 1973; Brach-Czaina, 1984; Jawłowska, 1988; Morawski, 1985, 2007; Cohn-Bendit, Dammann, 2008). W drugiej połowie XX w. zarówno w naukach społecznych, ruchach kontrkulturowych, jak i w „,nowej sztuce” podkreśla się, że każdy 
człowiek może być twórcą kultury dzięki aktywnej postawie i przekształcaniu zastanej sytuacji życiowej. Co więcej, humaniści zaczęli się zastanawiać nad przekładalnością sztuki na inne dziedziny ludzkiej egzystencji, a nawet na życie codzienne, pojawiła się idea „sztuki życia”, „życia estetycznego" jako dobrego życia. Zdaniem Richarda Rorty'ego (2009) polega ono m.in. na autokreacji, doskonaleniu się, samodzielnym i refleksyjnym przetwarzaniu wpływów socjalizacji, tworzeniu własnej drogi życiowej poprzez poszukiwanie, badanie i rozwiązywanie problemów poznawczych oraz praktycznych. Współcześnie coraz częściej, m.in. w konsekwencji wspomnianych przemian kulturowych i obyczajowych, socjolodzy sztuki swoje zainteresowania badawcze kierują ku strukturom i funkcjonowaniu środowisk artystycznych, sieciom relacji w ich obrębie. Badacze zainteresowani są społecznymi wymiarami sztuki, socjologiczną interpretacją dzieł, a pedagodzy i psycholodzy twórczości warunkami sprzyjającymi i utrudniającymi podejmowanie aktywności twórczej przez osoby z różnorodnym wykształceniem, statusem społecznym, w różnym wieku. Przedmiotem badań socjologów i historyków sztuki są obecnie zarówno procesy nominowania wytworów artystycznych jako wybitne (głównie przez estetyków, krytyków, historyków sztuki), ale i procesy przynależne kulturze popularnej (np. powieść popularna, fenomen pisania blogów) oraz wzajemne zależności pomiędzy tymi przestrzeniami twórczości (Heinich, 2010).

Jeżeli chodzi o psychologiczne i pedagogiczne badania nad twórczością codzienną, to wpisują się one, $\mathrm{z}$ jednej strony, w egalitarny nurt badań nad twórczością, nie tylko jako uznanego społecznie produktu pracy twórczej, ale i osobowościowych procesów autokreacyjnych, z drugiej zaś strony we współczesne studia socjologiczne i antropologiczne nad codziennością i jej niuansami. Dlatego, dookreślając twórczość przymiotnikiem „codzienna”, odwołuję się do jej postrzegania we współczesnych naukach humanistycznych. Określenie „,codzienność” używane jest do opisania tego, co rutynowe, związane z pracą, dniem codziennym, ale również w znaczeniu ważnym dla tych rozważań jako sfery doświadczenia indywidualnego, prywatnego i zawodowego (Brach-Czaina, 1999; Sulima, 2000; Martin, 2003; Bogunia-Borowska, 2009; Golka, 2009; Sztompka, 2008, 2009).

Ostatnia dekada badań nad twórczością zaowocowała szeregiem stanowisk w dyskusji nad egalitarnym ujęciem twórczości. Mamy zatem do czynienia z twórczością powszechną, określaną też jako demokratyczna, przyziemna, zwyczajna, codzienna, ,przez małe t”. E. P. Torrance (1995) używa terminu grassroots creativity na określenie twórczości pierwotnej, dzięki której możliwe staje się rozwijanie twórczego myślenia oraz uczenie się umiejętności twórczych w różnych dziedzinach życia, nie tylko siłą tradycji uznane za twórcze. T. Ai-Girl i L. Lai-Chong (2004) przywołują termin adaptive creativity za S. M. Tatsuno. Z kolei K. Sawyer (2006) twórczością codzienną określa twórczość grupową, np. w trakcie treningów grupowych, a J. Swann i J. Maybin (2007) twórczość codzienną lokują w powszednich praktykach komunikacyjnych, umożliwiających przystosowanie się do nowych sytuacji, poprzez zmianę nawyków językowych. M. A. Pachucki, J. Lena, 
S. Topper (2010) przeprowadzili badania wśród studentów (128 osób), a zainteresowani byli problemem postrzegania własnej twórczości przez badane osoby. Okazało się, że studenci twórczość rozumieją szeroko, nie tylko jako działania artystyczne, ale kojarzą własną aktywność twórczą m.in. z kształtowaniem relacji społecznych. Od lat aktywnymi propagatorami i autorami koncepcji oraz badań empirycznych nad egalitarnym wymiarem twórczości są m.in.: Ruth Richards, Mark Runco oraz Anna Craft.

Definiowanie twórczości codziennej w trakcie ponad 20-letnich badań prowadzonych przez Ruth Richards ewoluowało od wąskiego - medycznego, do szerokiego - utożsamianego z postawą twórczą i samorealizacją. Ujmując problem chronologicznie, termin „twórczość codzienna” R. Richards określa następująco:

- we wcześniejszych publikacjach „twórczość codzienna” funkcjonuje u niej jako wskaźnik psychologiczny (Richards, 1988),

- w kolejnych publikacjach stosuje zamiennie inne określenia: osiągnięcia twórczości codziennej (everyday creative accomplishment, 1988; 1990), oryginalność codziennego życia (originality of everyday life, 1999), jeden z poziomów twórczych (level of creativity, 1997; 1999), sposób życia (way of life,1997).

Pisanie w kategoriach pedagogiczno-edukacyjnych pociąga za sobą zmianę języka. I tak artykuły z lat 80 . i 90. XX w. są bardziej „medyczne”, konkretne, natomiast ostatnie operują językiem o wiele bardziej metaforycznym, obrazowym, ale i niejednoznacznym (Kubicka, 2005; Świgulska, 2009). W kontekście tematyki niniejszego tomu istotne wydaje się przywołanie, wskazywanych przez Richards (2007, 2010), korzyści podmiotowych płynących z bycia twórczym na co dzień: postrzeganie siebie jako części większej całości, uważne doświadczanie codzienności, otwartość na nowe doświadczenia i wieloaspektowe postrzeganie otaczającej rzeczywistości, podejmowanie wysiłku związanego z kształtowaniem własnego życia, refleksyjne odnoszenie się do reguł społecznych przyswojonych na drodze socjalizacji, konfrontowanie się z własnymi słabościami i lękami.

Można zaryzykować stwierdzenie, że stosowany język i sposób myślenia do opisu twórczości codziennej prezentowany w ostatnich publikacjach autorki (Richards (ed.), 2007) wpisuje jej rozważania w krąg kulturowy określany jako New Age (bądź ponowoczesnością lub postmodernizmem). Przypisuje się mu m.in.: indywidualizm, perspektywę holistyczną i systemową, niedogmatyczność, kreatywność, nieostrość granic pojęciowych, subiektywną religijność, inkluzyjność, relatywizm (por. Kubiak, 2005).

Kolejny z wymienionych badaczy, Mark Runco, zakłada, że wszyscy jesteśmy zdolni do twórczych zachowań. Twórczy potencjał, rozumiany jako konstruowanie nowych i oryginalnych interpretacji własnych doświadczeń, zdaniem badacza, jest immanentnie wpisany w naturę ludzką. Według tego autora twórczość osobista dotyczy ścisłej interreakcji pomiędzy wytwarzaniem oryginalnych interpretacji doświadczeń, rozwagą oraz intencjonalnością działań (Runco, 1996, 2005, 2006, 2007; Świgulska, 2009). 
Twórczość przez małe „t” - zadaniem A. Craft - to dyspozycja umożliwiająca dostrzeganie, nazywanie i co więcej - rozwiązywanie problemów dnia codziennego oraz dokonywanie wyborów przybliżających do indywidualnych celów życiowych, czyli kształtowanie własnej, niepowtarzalnej drogi życia (Craft, 2000, 2001a, 2001b, 2010; Świgulska, 2009).

Koncepcje twórczości codziennej cieszą się szczególnym powodzeniem wśród autorów różnorodnych poradników myślenia i działania twórczego (Maisel, 2004; Kizevich, 2004). W jednym z nich autorstwa Jeffreya Yamaguchi (2005), zatytułowanym 52 projects. Randomacts of everyday creativity zostały umieszczone wyselekcjonowane pomysły stanowiące przykłady twórczości codziennej, głównie zrealizowane przez autora poradnika. Do napisania książki J. Yamaguchi zachęcony został pozytywnymi reakcjami internautów odwiedzających jego stronę. We wspomnianym poradniku twórczość codzienna rozumiana jest jako aktywność generująca nowe projekty życiowe. Synonimicznymi określeniami dla pojęcia projekt są: przedsięwzięcie, wyzwanie, pasja lub pomysł wzbogacający i upiększający codzienność. Mogą one przybierać formę jednorazowych i zarazem krótko trwających realizacji, a także długoterminowych działań - „począwszy od sztuki kulinarnej na aktywności literackiej skończywszy” (tamże, 2005, s. 1). Autor akcentuje, że projekt powinien być czymś nowym dla pomysłodawcy i zaskakującym dla otoczenia, wykraczającym poza zachowania rutynowe, powinien przynosić pożytek nie tylko osobie realizującej go, ale i najbliższemu otoczeniu. J. Yamaguchi sugeruje, że inspiracją może być najmniejsze wydarzenie dnia codziennego, głównego jednak źródła natchnienia autor upatruje we własnej biografii, wspomnieniach z różnych okresów życia.

Tabela 1

Twórczość codzienna - projekty

\begin{tabular}{|l|l|}
\hline \multicolumn{1}{|c|}{ Przykładowe projekty - jednorazowe } & \multicolumn{1}{|c|}{ Przykładowe projekty - długoterminowe } \\
\hline $\begin{array}{l}\text { 1. Zrób rano kilka zdjęć ukochanej osobie. Wy- } \\
\text { obraź sobie, o czym mogła wtedy śnić. }\end{array}$ & $\begin{array}{l}\text { 1. Wybierz swoją ulubioną książkę. Potem } \\
\text { pójdź do biblioteki i wyszukaj inne książki } \\
\text { tego samego autora. Znajdź pierwszą, którą } \\
\text { wydał. Prześledź, jakie tematy poruszał, jak } \\
\text { ewoluowała jego twórczość. Zainteresuj się } \\
\text { jego biografią i jego inspiracjami literackimi. } \\
\text { Zainteresuj innych swoimi odkryciami. }\end{array}$ \\
\hline $\begin{array}{l}\text { 2. Napisz ołówkiem komentarz na marginesie } \\
\text { książki, która zrobiła na tobie wrażenie. Na- } \\
\text { stępnie sprzedaj ją do antykwariatu. Ważne, aby } \\
\text { książka z komentarzem znalazła się w obiegu. }\end{array}$ & $\begin{array}{l}\text { 2. Spróbuj regularnie pisać krótkie opowiada- } \\
\text { nia, dla których inspiracją będą bieżące wyda- } \\
\text { Możenia z twojego życia, przeprowadzki, spotka- } \\
\text { ne osoby, nagłe sytuacje, przeczytane książki, } \\
\text { sjami w książce, którą właśnie przeczytałeś. } \\
\text { obejrzane filmy. Przeczytaj, stwórz literackie } \\
\text { koło osiedlowe. }\end{array}$ \\
\hline
\end{tabular}

Źródło: oprac. własne na podstawie J. Yamaguchi, 2005. 
W mediach kultury masowej i popularnej, zwłaszcza „demokratycznym” Internecie, odnajdujemy szereg propozycji rozwijania twórczości egalitarnej, nierzadko określanych właśnie twórczością codzienną․ Dominującym tutaj podejściem do twórczości jest utożsamianie jej ze sztuką amatorską i podejmowaniem pracy nad transformacją własnej osobowości. Takie rozumienie twórczości $\mathrm{w}$ świadomości potocznej wpisuje ją w temat zakorzeniony w kulturze ponowoczesności, ale i myśli rozwijane w ramach nurtu określanego psychologią pozytywną (Seligmann, 2005; Czapiński, 2004; Trzebińska, 2008; Carr, 2009; zob. artykuł K. J. Szmidta w tym tomie).

Analiza literatury przedmiotu oraz badania własne prowadzą mnie do wniosku, że można wyróżnić dwa podstawowe rozumienia twórczości codziennej ze względu na zakres tego pojęcia:

- szerokie - twórczość codzienna traktowana jako przejaw ewolucji i zdolności adaptacyjnych człowieka, naturalna droga osiągania coraz to wyższych poziomów rozwoju - od przystosowania do istniejących warunków życia, poprzez twórczą adaptację aż do twórczości w dniu powszednim;

- wąskie - wydające się ciekawszym ze względu na walory poznawcze i implikacje empiryczne: twórczość codzienna to aktywność człowieka, której efektem są zachowania i/lub wytwory traktowane przez podmiot działający jako jednocześnie nowe i wartościowe. Aktywność ta może być realizowana w formach obserwowalnych działań powszednich i okolicznościowych. W powyższej definicji zwraca się uwagę na dwie rzeczy zwyczajowo traktowane rozłącznie. $Z$ jednej strony, sam podmiot działający wartościuje swe zachowania jako nowe i wartościowe (aspekt subiektywny). Z drugiej strony, te zachowania i wytwory, jako uchwytne z zewnątrz, mogą być uznane za nowe i wartościowe przez obserwatora (aspekt obiektywny). Twórczość codzienna łączy się z oboma sposobami wartościowań, niemniej w świadomości społecznej (naukowej i potocznej) bardziej eksponowany jest aspekt subiektywny. Dzieje się tak dlatego, że powyższe rozumienie twórczości codziennej przywołuje na myśl terminy samorealizacji i autokreacji, które w literaturze pedagogicznej często są zamiennie używane (Dudzikowa, 1994; Jankowski, 2000; Pietrasiński, 1988; Schulz, 1990; Szmidt, 2001, 2002; Uszyńska-Jarmoc, 2007).

Podsumowując, można stwierdzić, że twórczość egalitarna/codzienna postrzegana jest przeważnie w literaturze przedmiotu jako ta, która nie wymaga „wtajemniczenia" i nie jest uwikłana w instytucjonalny kontekst stawania się profesjonalnym twórcą w tradycyjnych dziedzinach twórczości. Tworzenie, jak chcą głównie pedagodzy, nie może zostać ograniczone jedynie do działania w środowiskach

${ }^{2}$ http://www.teras-wish.com/whatisi.htm; http://www.creativityandcognition09.org/; http://creativeeveryday.com/; http://www.psychologytoday.com/articles/200910/everyday-creativity; http:// eprints.qut.edu.au/5056/; http://applij.oxfordjournals.org/cgi/content/abstract/28/4/497; http://shamurai.com/sites/creativity/papers/9.perkel.pdf; http:/www.bellaonline.com/articles/art15925.asp. 
profesjonalistów, ale dotyczy również tych, którzy szukają nowych rozwiązań starych problemów życia codziennego, podejmują wysiłek rozwojowy, aktualizują swój potencjał osobowościowy. Dodałabym, że również biograficzny. Zarówno „krytyczne” koncepcje twórczości codziennej, jak i „potoczne” ujmują ją jako aktywność przynoszącą pozytywne zmiany w życiu człowieka, umożliwiające skuteczne rozwiązywanie codziennych problemów osobistych oraz zawodowych; a co więcej, sprzyjającą rozwojowi osobistemu. Koncepcje twórczości codziennej, które pojawily się zarówno w pracach naukowych oraz mediach kultury popularnej rozgraniczyłam na „krytyczne” (profesjonalne, naukowe) oraz potoczne (naiwne). Powyższe rozróżnienie dokonane zostało na podstawie literatury z zakresu komparatystyki wiedzy naukowej i potocznej, w której za określeniem myślenie (postawa) potoczne kryją się następujące cechy: obiegowe i niesprawdzone, przyjęte na wiarę, jawne bądź ukryte przekonania kształtujące światopogląd członków danej społeczności (Garfinkel, 1984; Hołówka, 1986; Maruszewski, 1986; Lachowicz-Tabaczek, 2004).

Wiesława Limont (2003, s. 18) pisze, że „twórczość codzienną należy rozumieć jako podmiotową kreatywność, pozwalającą uznać za twórcze każde rozwiązywanie zadania, które w minimalnym stopniu zmienia zastaną sytuację wewnętrzną lub zewnętrzną". W konsekwencji, mówiąc językiem psychologii pozytywnej, twórczość egalitarna/codzienna i jej wytwory postrzegane są jako zasoby przyczyniające się do poprawy jakości życia na co dzień.

Przedstawiciele psychologii pozytywnej twórczość/postawę twórczą traktują i badają jako kardynalne cnoty, sprzyjające szczęściu, autonomii i urzeczywistnianiu własnego potencjału rozwojowego obok innych właściwości psychicznych, takich jak: umiejętność przebaczania, wdzięczność, duchowość, nadzieja, poczucie sensu, optymizm, poczucie własnej wartości (Seligman, 2005; Czapiński, 2004; Trzebińska, 2008; Carr, 2009). Martin Seligman (2005), ojciec psychologii pozytywnej, uważa, że dobre życie polega na codziennym wykorzystywaniu swoich osobistych zalet i kompetencji sygnaturowych, a wśród nich na pierwszym miejscu figuruje mądrość. Owa siła charakteru wiąże się z nabywaniem i wykorzystywaniem wiedzy oraz własnego doświadczenia, a w tym procesie, jak pisze M. Seligman, kluczową rolę pełni postawa twórcza i ciekawość poznawcza oraz otwartość na doświadczenia. Twórczość rozumiana jest jako pomysłowość, produktywność i nowatorskie podejście do różnych spraw, ciekawość utożsamiona została w koncepcji badacza z wnikliwością poznawczą, dociekliwością i wnikliwym zainteresowaniem światem wokół nas, z kolei otwartość to wielostronne percypowanie rzeczywistości (Seligman, 2005). Jak dalej się okaże, badane przeze mnie osoby twórczość codzienną postrzegały właśnie jako siłę, energię umożliwiającą, na przykład, doprowadzenie rozpoczętych pomysłów do końca, a co ważniejsze - zachęcającą do odważnego redefiniowania własnego funkcjonowania w różnych kontekstach życiowych. 
Szerokie definiowanie pojęcia twórczość, zwłaszcza poprzez dookreślenie jej przymiotnikami „egalitarna”, „,codzienna”, czyni je pojęciem bardzo pojemnym, być może nieostrym. Pojawiają się także pytania: w jaki sposób odróżnić twórczość od nie-twórczości? Czy egalitarne podejście do twórczości nie jest podyktowane potrzebą dowartościowania działań zwykłych, oczywistych, rozwojowych? Pojawienie się koncepcji, badań i poradników podejmujących temat twórczości codziennej jest również przykładem przenikania, uzupełniania się i wzajemnej inspiracji rozważań „akademickich” i popularnonaukowych, jak i wyrazem kulturowego współmyślenia o tym, co można nazwać twórczym i kogo - twórcą. Zastanawiam się, czy nie byłoby lepiej pisać o twórczości „oficjalnej” (instytucjonalnej), związanej z konkretnymi instytucjami edukacyjnymi oraz lub/i docenionej nagrodami, stypendiami, wystawami, cytowaniami; oraz twórczości „nieoficjalnej”, tworzonej poza daną dziedziną i środowiskiem twórczym. Wyróżnianie biegunów twórczości w literaturze psychologicznej i pedagogicznej ma raczej charakter porządkujący i teoretyczny, nierzadko trudny do zastosowania przy opisywaniu twórczości konkretnych osób. Wydaje się, że bardziej przydatne może być postrzeganie biegunów twórczości jako wzajemnie inspirujących się perspektyw oraz sieci zależności treści, form, instytucji czy relacji interpersonalnych sprzyjających powstawaniu nowych i wartościowych wytworów.

\section{Twórczość oficjalna i nieoficjalna}

Opisane poniżej przykłady mogą obrazować przenikanie twórczości wysokiej (instytucjonalnej, uznanej społecznie) i codziennej (nieinstytucjonalnej). Wymienieni poniżej twórcy kojarzeni bywają przeważnie z twórczością, za którą są nagradzani; funkcjonują zatem w obiegu danej dziedziny. Ich tworzenie jednak nie ogranicza się do jednej dziedziny, siłą tradycji uznanej za twórczą.

Wisława Szymborska jest autorką nie tylko poezji, za którą otrzymała w 1996 r. literacką Nagrodę Nobla, od wielu lat tworzyła również wyklejanki i kartki pocztowe, którymi obdarowywała przyjaciół i znajomych, wykorzystując do nich przeróżny materiał - fragmenty ilustracji, napisów, gazet, opakowań. Treść wyklejanek bywa rozmaita: od absurdów po komentarze aktualnych wydarzeń z życia pisarki, jak również zdarzeń globalnych. Są one przykładem abstrakcyjnego $i$ absurdalnego poczucia humoru poetki, który przejawiał się również w limerykach, nierzadko pisanych w podróżach, i dedykacjach czy życzeniach zamieszczanych właśnie na własnoręcznie przygotowanych wyklejankach ${ }^{3}$. Owe wyklejanki i limeryki mają charakter ludyczny, stanowią nieoficjalną twórczość poetki, stały się jednak pretekstem i inspiracją do napisania książek. Odsyłam czytelników do książek: przyjaciela Wisławy Szymborskiej, Ryszarda Matuszewskiego - Wistawy Szymborskiej dary przyjaźni i dowcipu oraz Anny Bikont, Joanny Szczęsnej - Wisławy pamiątkowe rupiecie, przyjaciele i sny oraz publikacji samej

\footnotetext{
${ }^{3}$ http://wyborcza.pl/1,91446,8959307,Wislawa_Szymborska_poetka_i_noblistka.html\#ixzz1BUVv4BOv
} 
poetki - Rymowanki dla dużych dzieci z wyklejankami Autorki. A oto przykład dedykacji i życzeń świątecznych dla R. Matuszewskiego i jego żony:

Panie Ryszardzie, jeżeli Panu nie obrzydta jeszcze poezja, to proszę przyjąc te wiersze, które wypetniaja bolesna lukę między Szekspirem a Hermenegilda Kociubinska;

Kochany Ryszardzie! Pewnie zbrzydty ci te wiersze, czytane jeszcze w maszynopisie. Dlatego ksiażeczkę ozdobiłam jak mogłam. A w ogóle to bardzo, bardzo Ci za wszystko dziękuję! I przepraszam za wszystkie błędy w tych wierszach: ortograficzne, stylistyczne, polityczne, administracyjne, a przede wszystkim artystyczne - Wistawa.

Kraków, 16 grudnia 1984. Kochani, Dalszego doskonalenia systemu funkcjonowania gospodarki, Dalszego wzrostu działań na rzecz obronności kraju i umacniania rodziny w świetle uchwat, Dalszych osiagnięć na odcinku kultury w świetle pozytywnych przemian i nadwyżek rolnych, Dalszej likwidacji tragicznych skutków zimy 78 roku, Dalszego rozwoju zaawansowania procesów w walce z przejawami oraz Wesolych Świat życzy Wisława (Matuszewski, 2008).

Kolejny twórca, subiektywnie wybrany, to Paul Cézanne, samotnik, którego malarstwo inspirowało awangardowych twórców XX w. Malarz jest autorem wielu listów m.in. do Emila Zoli, w których głównie rejestruje swoją codzienność, ale i poglądy dotyczące malarstwa, roli artysty, stosunku do tradycji, natury, technik pracy malarskiej. Listy odsłaniają człowieka dowcipnego, zwłaszcza te z młodości, nieokrzesanego, pełnego pasji. Tak w jednym z listów z 1859 r. do Emila Zoli zaczyna opis pewnego zdarzenia, prawdę mówiąc, to cały list został napisany w poetyckiej konwencji:

To się zdarzyło w nocy Zechciej przytem zważyć,

Że noc czarna, gdy nawet gwiazdka się nie żarzy,

Gdy się zdarzyla owa historia poczwarna.

To straszne, nienazwane, co się wtedy stato,

To dramat, o jakim ucho ludzkie nie styszało (Cézanne, 1968).

Z kolei Albert Einstein muzykował na skrzypcach. Siostra geniusza wspomina, że gra inspirowała i podsuwała mu rozwiązania problemów, nad którymi pracował (Brian, 1997).

Peter Zumthor, jeden z najsłynniejszych współczesnych architektów, laureat ,architektonicznego Nobla”, humanista, autor przepięknej książki - Myślenie architektura - muzykuje, posiada specjalnie do tego zaprojektowany pokój muzyczny. Tak pisze w swojej książce, która stanowi autobiograficzny rejestr doświadczanych różnych przestrzeni, jak i inspiracji dla pracy zawodowej architekta, w tym i muzyki właśnie: „Myślę, że współczesna architektura w gruncie rzeczy powinna przyjąć równie radykalne podejście co muzyka nowoczesna" (Zumthor, 2010, s. 12). 


\title{
2. Założenia badań własnych nad kategorią twórczości codziennej
}

\begin{abstract}
Uczono nas tutaj, że świat da się opisać, a nawet wyjaśnić za pomocą prostych odpowiedzi na inteligentne pytania. Że w swej istocie jest bezwładny i martwy, że rządzą nim dość proste prawa, które należy wyjaśniać i podać - najlepiej wykorzystując diagram. Domagano się od nas eksperymentów. Formułowania hipotez. Weryfikowania. Wprowadzano nas w tajemnice statystyki, wierząc, że za jej pomocą można doskonale opisać wszelkie prawidłowości świata - że 90 procent jest bardziej znaczące od 5 .
\end{abstract}

Tokarczuk, 2007, s. 16

Istotnym elementem mojej perspektywy jest teza o narracyjnym charakterze autobiografii, pojmowana jako próba refleksyjnego zrozumienia własnej historii życia oraz jej uporządkowania (por. Bogusławski; Modrzejewska-Świgulska, 2011). Zakładam również, że owo uporządkowanie (reinterpretowanie przeszłości, reflektowanie teraźniejszości, antycypowanie przyszłości) może być opisywane jako twórczy potencjał człowieka, wspierający jednocześnie jego dobrostan. Twórczy charakter narracji autobiograficznych przejawiałby się, między innymi, w spójnym powiązaniu elementów własnych dziejów, dzięki któremu można reinterpretować porażki jako sytuacje zmuszające do zmiany nawyków myślenia i działania. Warto tutaj zauważyć, że jedną ze zdolności twórczych, a nawet rodzajów twórczości, jest właśnie umiejętność transformowania i modyfikowania idei, obrazów, wyobrażeń, szkiców (Boden, 2010). W przypadku ,pracy autobiograficznej” nie tylko chodziłoby o reinterpretację doświadczeń (transformację), inaczej mówiąc zobaczenie tego, co nam się przydarzyło, konsekwencji naszych wyborów w nowym, „lepszym”, świetle, ale i włączenie myślenia życzeniowego, projektującego przyszłość. Takie podejście do własnej historii życia pomaga radzić sobie $\mathrm{z}$ trudnymi sytuacjami, odpowiada na potrzeby samookreślenia i nadawania sensu własnym doświadczeniom oraz wyborom życiowym.

Materiał empiryczny, będący podstawą tych rozważań, pozyskany został na drodze wywiadów narracyjnych w celu zrekonstruowania społecznych i osobowościowych czynników warunkujących twórcze działania rozmówców, czyli pedagogów/ nauczycieli ${ }^{4}$ działających na rzecz Polskiego Stowarzyszenia Kreatywności ${ }^{5}$. Zatem

${ }^{4}$ Badania prowadzone były w ramach pracy doktorskiej napisanej pod kierunkiem prof. K. J. Szmidta (UŁ). Dwunastu narratorów pochodzi z różnych stron Polski: Łodzi, Poznania, Krakowa, Warszawy i mniejszych miejscowości usytuowanych w okolicy Łodzi.

${ }^{5}$ Stowarzyszenie zostało założone w 2000 r. i integruje pedagogów, nauczycieli, psychologów i animatorów kultury oraz przedstawicieli innych zawodów zainteresowanych teoretycznymi 
badania narracyjno-biograficzne prowadzone były po to, aby pozyskać opisy warunków determinujących twórczy sposób życia badanych. Mam tu na myśli wszystko to, co wykształciło potrzebę poszukiwania oraz aplikowania nowych i wartościowych projektów życiowych, umożliwiających narratorom pozytywne sposoby realizowania własnej biografii. Problemy badawcze pełniły raczej funkcję ogólnych wytycznych, sygnalizujących zagadnienia, które będą analizowane przez badacza. Główny problem podjętych badań został sformułowany w postaci następującego pytania: Jak badani pedagodzy uprawiają (realizują) twórczość codzienną? Główny problem doprecyzowany został poprzez następujące pytania szczegółowe: W jaki sposób tworzą twórcy codzienni?; Jakie procesy intelektualne, emocjonalne, motywacyjne oraz behawioralne biorą udział w powstawaniu nowego i wartościowego produktu?; Jakie przejawy (wytwory) twórczości codziennej występują u badanych?; Jakie czynniki wpływają na podejmowanie twórczości codziennej oraz jej kontynuowanie?; Jakie czynniki wpływają na zaprzestanie twórczości codziennej?; Jaka jest cecha znacząca ich biografii? (zob. Modrzejewska-Świgulska, 2010; Świgulska, 2010).

W niniejszym opracowaniu odniosę się do wybranego materiału empirycznego. Głównym celem moich badań było opisanie zjawiska twórczości codziennej poprzez pryzmat rekonstruowanych biografii tematycznych. Celem pedagogicznych badań biograficznych może być poznanie biografii tematycznej skoncentrowanej na problemie, temacie interesującym badacza (por. Gardner, 1988; Gruber, 1989; Szmidt, 2007). Dlatego biografia jako taka nie była bezpośrednim przedmiotem moich zainteresowań badawczych, ale konkretne zjawisko praktyki społecznej - twórczość codzienna jako pewien styl życia. A zatem metodę biograficzną traktuję tutaj jako sposób na zrekonstruowanie biograficznego porządku zdarzeń życiowych, które mogły wpłynąć na podejmowanie działań twórczych przez badane osoby (por. Helling, 1990). Dodatkowo miałam możliwość zapoznania się z pisanymi i obrazowymi dokumentami zastanymi, czyli wykonanymi w sytuacjach poza badawczych, oraz wizytowałam placówki zarządzane przez niektórych z narratorów.

\subsection{Twórczość codzienna w narracjach pedagogów ${ }^{6}$}

Twórczość codzienna opisywana była przez narratorów przede wszystkim jako skuteczne rozwiązywanie problemów i możliwość wpływania na własne życie. Nie unikali oni tematów bolesnych, związanych bardzo często z sytuacjami

\footnotetext{
i praktycznymi problemami rozwijania potencjału twórczego zarówno u siebie, jak i u innych. PSK jest również przestrzenią komunikacji społecznej polegającej na wymianie doświadczeń oraz wzajemnym wspieraniu się we własnych dążeniach rozwojowych. Zob. http://www.p-s-k.pl.

${ }^{6}$ Problematyka znalazła odbicie w pracy K. J. Szmidt, Pedagogika twórczości, wyd. 2, GWP, Gdańsk (w druku).
} 
losowymi oraz trudnymi relacjami z najbliższymi, w konsekwencji niektórzy snuli opowieści o tym, jak radzili sobie z tym, co trudne na ich drodze życia.

Wytwory twórczości codziennej można uszeregować według następujących kryteriów: perspektywy czasowej, zaangażowania narratorów, złożoności realizowanych zadań twórczych. Dlatego narratorzy uznali za wytwory twórcze te niewymagające wiedzy ani specjalnych umiejętności, powstające spontanicznie. Biorąc pod uwagę perspektywę czasową, są to zadania jednorazowe, niepoddane dalszej obróbce, głównie podejmowane dla rozrywki, integracji z grupą, urozmaicenia działań rutynowych czy spotkań towarzyskich, można określić je słowem paidia bądź „twórczością amatorską" - terminem przyjętym w pedagogice (Szmidt, w druku). Przez narratorów nazywane np.: „twórczością radosną”.

Drugi poziom obejmuje już wytwory wymagające rozwiązania jakiegoś problemu osobistego bądź zawodowego, a zatem cierpliwości, wysiłku, odwagi, opanowania konkretnych umiejętności i wiedzy, przełamania barier kulturowych, które można określić słowem ludus bądź „twórczością profesjonalną”, lub „quasi-profesjonalną". Na tym poziomie twórczość powodowana jest potrzebą samoedukacji i samorealizacji, podnoszenia jakości życia, czynienia go lepszym, piękniejszym, bardziej produktywnym. Ważne są tu też względy ekonomiczne - podejmowanie aktywności twórczej dla polepszenia sytuacji materialnej. W konsekwencji twórczość codzienna manifestuje się nowymi i długoterminowymi projektami życiowymi np.: zawodowymi (np. opracowanie autorskiej strategii rozwijania zdolności twórczych u dzieci, założenia placówki edukacyjnej według własnego pomysłu, rozwiązanie problemu związanego z nagłą utratą pracy), społecznymi (np. animowanie społeczności lokalnej na rzecz ratowania ginących, starych cmentarzy), osobistymi (podjęcie decyzji i przeprowadzenie sprawy rozwodowej, radzenie sobie z chorobą nowotworową).

Narracje ujawniły dwa podstawowe wymiary działań twórczych narratorów. Podmiotowy - narratorzy skojarzyli go $\mathrm{z}$ wewnątrzsterownością i potrzebą przekształcania zastanych sytuacji życiowych. Środowiskowy kontekst twórczości codziennej - dotyczył funkcjonowania narratorów w grupach społecznych, zwłaszcza zawodowych. Narratorzy podkreślali potrzebę przynależności i współpracy np. ze stowarzyszeniami, kolegami z pracy. $Z$ drugiej strony opowiadali, że wprowadzane przez nich innowacje w miejscu pracy, zwłaszcza w szkołach czy przedszkolach, nierzadko stawały się źródłem konfliktu z innymi nauczycielami oraz brakiem wsparcia ze strony przełożonych. Scalając materiał badawczy, udało się wyróżnić doświadczenia biograficzne prawdopodobnie sprzyjające rozwojowi kreatywności narratorów:

- w okresie dzieciństwa i adolescencji: np. możliwość eksplorowania najbliższego otoczenia i rozwijania zainteresowań, spotkania z ważnymi nauczycielami;

- w okresie studiów i obecnie: np. możliwość konfrontacji własnych pomysłów z osobami o podobnych zainteresowaniach, możliwość pracy na rzecz organizacji, stowarzyszeń, w których można sukcesywnie zdobywać nowe doświadczenia i wiedzę; 
- doświadczenia krystalizujące ${ }^{7}$ : m.in. utrata pracy i poczucie samotności, zajęcia nakierowane na samorozwój, ale i warsztaty promujące aktywne metody nauczania, opisywane były jako momenty wpływające na zmianę postrzegania siebie jako reprezentanta profesji pedagogicznej, ale i osobę odpowiedzialną za własny rozwój będący zarówno warunkiem samopoznania, jak i działań prospołecznych.

\subsection{Narracje autobiograficzne w kontekście twórczości codziennej}

W narracjach dotyczących kategorii twórczości codziennej udało się wyróżnić charakterystyczne sposoby organizowania doświadczeń biograficznych (wątki autobiograficzne) (zob. Świgulska, 2010). Zaproponowane wątki wymagają oczywiście dalszych eksploracji badawczych, mają charakter propedeutyczny. Każdy z wątków charakteryzowany jest na podstawie typu działań bohatera, jego decyzji życiowych oraz reakcji na wydarzenia losowe (Tokarska, 1999; Trzebiński, 2002; Stemplewska-Żakowicz, 2002). Zawierają przeważnie informacje o własnej skuteczności i oddziaływaniu na środowisko (Oleś, 2009). Oczywiście możemy zadać sobie pytanie, na ile wyróżnione wątki rzeczywiście kształtowały pozyskane opowieści, a na ile zostały wpisane w autonarrację przez interpretatora/ badacza narracji. Pozyskane wypowiedzi o twórczości codziennej nie były jedynie sprawozdawczymi, wiernymi relacjami z życia narratorów, ale procesem stricte twórczym, polegającym na selekcji i interpretacji zdarzeń. Hipotetycznie można założyć, że rozmówcy, opowiadając o twórczości codziennej, wpisali swoje autonarracje w ogólne wątki kulturowe, które obrazują życie jako zadanie. W „małych i wielkich narracjach”, czyli m.in. mitach, literaturze pięknej oraz narracjach biograficznych/autonarracjach, badacze wyróżnili kilka ogólnych, symboliczno-metaforycznych wątków narracyjnych, porządkujących ludzkie doświadczenie - toczenie walki o własne ja (np. symbolicznej), budowanie wspólnoty, podejmowanie podróży symbolicznej i fizycznej (poszukiwanie tożsamości, własnego miejsca), przeżywanie i znoszenie bólu, cierpienia (godzenie się z losem) oraz poszukiwanie dopelnienia (Campbell, 1997; Elsbree, za: Tokarska, 1999; Pieniążek, 1999; Świgulska, 2010).

Również w opowieściach na rzecz twórczości codziennej można próbować wyróżnić następujące wątki/tematy biograficzne:

${ }^{7}$ „Doświadczenia krystalizujące” mają fokusować uwagę twórcy na danym problemie czy to naukowym, czy artystycznym. H. Gardner wyróżnia dwa rodzaje doświadczeń krystalizujących: początkowe i precyzujące, doskonalące dalszą pracę twórczą (Stasiakiewicz, 1999). 


\title{
Budowanie wspólnoty i praca na jej rzecz
}

\begin{abstract}
Ja postrzegam swoje życie jako służbę innym, jako «bielanka» [dziewczęca służba kościelna - M. M.-Ś.] opiekowałam się starszymi, w harcerstwie tak było, że odpowiedzialna byłam za innych, ciągle dla kogoś. Myślę sobie, że do dzisiaj tak jest, moja rola jest na zasadzie pomocnika, przyjaciela, nauczyciela, żeby pomóc dzieciom, aby one rozkwitały. Rodzinę też tak rozumiem, jestem po to, aby swoim dzieciom służyć radą. To jest ciągle dla kogoś, aczkolwiek nie ukrywam, daje mi to satysfakcję.
\end{abstract}

„Harcerka”

Działania narratorów motywowane są potrzebą niesienia pomocy innym, ale i potrzebą współpracy w ramach wybranych grup odniesienia - szkolnych (np. praca na rzecz samorządu szkolnego, harcerstwo, służba kościelna, stowarzyszenia), jak również chęcią przewodzenia tym grupom, np. grupom rówieśniczym ${ }^{8}$. Wątkiem centralnym tych opowieści jest chęć budowania i współtworzenia dobra społecznego danej wspólnoty (np. lokalnej). Działania badanych można by określić jako animacja społeczno-kulturalna, nierzadko pełnią oni funkcje liderów. Opowieści przeważnie konstruowane są wokół wątku ja a grupa; ja dla grupy, chronologicznie opowiedziane, ale chronologia budowana jest w oparciu o uczestniczenie w działaniach danej grupy i realizowanie długoterminowych zobowiązań. Dominującym motywem tych powieści stała się praca zawodowa i społeczna (Świgulska, 2010).

\section{Toczenie walki o wlasne Ja, protest jako element podtrzymywania własnej indywidualności}

Moja droga do samookreślenia była trudna jak przedzieranie się przez dżunglę własnych lęków i świadomości bycia niedoskonałą, było to trudne.

„Artystka”

Można przyjąć, że narratorzy w swojej opowieści prezentują „,biograficzny schemat działania", czyli intencjonalne kształtowanie siebie (autokreację),

\footnotetext{
${ }^{8}$ Jedna z badanych tak zaczyna opowieść o twórczości codziennej: „Sięgając wstecz, uwielbiałam wymyślać zabawy i przewodziłam w tych zabawach, to jest moja cecha, która może być pozytywna i negatywna, wymyślanie zabaw i rozdzielanie ról”.

${ }^{9} \mathrm{~K}$. Kaźmierska, Wywiad narracyjny jako jedna z metod w badaniach biograficznych, „Przegląd Socjologiczny", 2004, t. LIII/1.
} 
a co więcej - podejmowanie walki o własną niezależność i „niepowtarzalną” biografię. Narratorzy posiadają własny plan realizacji określonych zamierzeń, pracy nad własnym rozwojem, np. konsekwentnie realizowany plan edukacji zawodowej związanej z edukacją plastyczną oraz pedagogiką. Ponadto przejawiają potrzebę nowych form biograficznych, podejmują się coraz to nowych aktywności i zadań na rzecz rozwijania własnych zainteresowań, nierzadko związanych z pracą zawodową. Ważną rolę w kształtowaniu się obrazu własnej osoby u narratorów odgrywają działania artystyczne. W opowieściach pojawiają się nauczyciele, od których można uczyć się nowych umiejętności i - co ważniejsze - wzorować na nich, pełnią oni funkcję wychowawców/mentorów. Narratorzy nierzadko kształtują swoją tożsamość poprzez sprzeciw wobec dotychczasowego życia, nie chcą żyć jak ich rodziny (jedna z narratorek „ucieka” od życia wiejskiego). Motywy, które kierują ich wyborami dotyczącymi drogi edukacyjnej są związane z potrzebą samookreślenia i spełnienia (Świgulska, 2010). Opowieści te mogą wydawać się chaotyczne i nieuporządkowane, bo nie są prowadzone według tradycyjnej narracji liniowej, chronologicznej, ale przypominają raczej wypowiedziany monolog wewnętrzny.

\section{Przeżywanie i radzenie sobie z trudnościami (losem)}

\begin{abstract}
Teraz przyjmuję to, co mi przyniesie los. Zresztą, gdybym nie musiała przenieść się z jednego przedszkola... Co zresztą bardzo odczułam. [...] Dlaczego ja ci o tym mówię, bo w zasadzie nie musiałabym ci o tym mówić, ale to był przełomowy moment w moim życiu. Dlaczego, bo wtedy w zasadzie uświadomiłam sobie, aha, poczułam się sama. [...] Do czego zmierzam, gdyby nie to, że zostałam sama, bez pomocy, to nie odważyłabym się przyjść na seminarium.
\end{abstract}

„Badaczka”

Ważnym wątkiem tych opowieści stała się „,biograficzna metamorfoza” (Kaźmierska, 2004), czyli pozytywna zmiana w życiu jednostki spowodowana presją świata zewnętrznego, sytuacją losową i zaskakującą. Choroba nowotworowa, utrata pracy, osamotnienie w środowisku zawodowym, rozwód, brak porozumienia z najbliższymi zmusza narratorów do przeformułowania własnych celów życiowych, zawodowych i osobistych. Wspominane wydarzenia pozwoliły im odkryć nowe możliwości i znaleźć siły, aby przebudować własny los. Narratorzy próbują godzić się z losem w taki sposób, że szukają nowych rozwiązań życiowych, poszukują nowych aktywności, zadań, przestrzeni społecznej i innych, z którymi mogą realizować swoje plany osobiste i zawodowe. Narratorzy ,przekuwają” problemy 
życiowe na własną korzyść, czyli wykorzystują je rozwojowo, dokonują „transgresji osobistej” (por. Kozielecki, 1992).

\section{Podejmowanie podróży twórczej symbolicznej i fizycznej}

\begin{abstract}
Pasja historyczna, to znaczy, jak gdzieś się jedzie, chciałoby się zobaczyć coś intrygującego, i odkrywa się świat, którego do tej pory się nie widziało, jakiś obraz, budowlę, rzeźbę, coś co wzbogaca wiadomości z danej dziedziny, potem się szuka czegoś na ten temat.
\end{abstract}

„Turysta”

Ta opowieść o twórczości codziennej zdaje się pochodzić od człowieka będącego w ciągłym ruchu. Twórczość badanego jest konsekwencją jego rozmaitych podróży, a co za tym idzie - wynika z przemieszczania. Jego narracja wydaje się dużo bardziej oszczędna w słowach niż pozostałych narratorów. Odsłuchując nagranie wywiadu, ma się wrażenie, iż narrator waży słowa jak kroki podczas wędrówki, aby rozłożyć siły na cały czas jej trwania. Opowieść przypomina dziennik z podróży zapisany krótkimi, sprawozdawczymi notkami z jej kolejnych etapów. Nie powinno więc dziwić, iż pojęcia czasu i przestrzeni są istotnymi elementami tej opowieści o twórczości codziennej - te dwie współzależne kategorie strukturalizują narrację. Poprzez swoją opowieść badany przemierza czas i przestrzeń, a aktywność twórczą narrator podporządkował podróżowaniu i jest ono konsekwencją doświadczanej przez niego przestrzeni. To właśnie podróż przywołał jako prymarną dziedzinę działań twórczych w stosunku do innych aktywności, które z niej wypływają. Narrator, snując swoją opowieść, czyni motyw podróżowania i wędrowania osią kompozycyjną, wątkiem nadrzędnym. W swojej wypowiedzi relacjonuje, jak poznawanie nowych miejsc wpływało na jego zainteresowania i twórczą aktywność. Podróż symboliczna rozmówcy to próba odnalezienia własnej tożsamości, zapewne dlatego w opowieści rozmyśla, co jest dla niego ważne oraz to, że nie chce zmarnować danego mu czasu. Przejawia potrzebę zostawienia po sobie śladu, dokumentowania przemijających miejsc. Podróż przynosi zmiany, ruch, urozmaicenia, okresy twórcze przeplatają się u badanego z okresami impasu twórczego, kryzysu.

\section{Podsumowanie}

Narracje pozyskane na rzecz kategorii twórczości codziennej określiłabym jako przykłady „udanej biografizacji”. „Udana biografizacja [...] pozwala chronić pozytywny obraz własnej osoby [...]" (Urbaniak-Zając, 2005, s. 122). Co więcej, 
opowieści o twórczości codziennej wpisują się jednocześnie w perspektywę pedagogiczną analizującą możliwość intencjonalnego kształtowania własnej biografii (życia) (Urbaniak-Zając, 2005; Lalak, 2010; Bogusławski, Modrzejewska, 2011). Zatem badani opowiadali o swojej aktywności wynikającej z ich inicjatywy i potrzeby spełnienia się głównie w tych dwóch obszarach życiowych. Często pojawiające się wątki tematyczne dotyczą również potrzeby ekspresji twórczej oraz działań społecznych. Chociaż nie unikali oni tematów trudnych, związanych bardzo często z sytuacjami losowymi oraz skomplikowanymi relacjami z najbliższymi, w konsekwencji snuli opowieści o tym, jak radzili sobie z tym, co zaskakujące na ich drodze życia. Czyżby twórczość codzienna kojarzyła się rozmówcom przede wszystkim z ich zasobami, siłą i możliwością wpływania na własne życie? Jeżeli tak, to można wstępnie założyć, że twórcze dzialania narratorów wspierają ich subiektywny dobrostan (stan w osobistej perspektywie oceniony jako korzystny dla rozwoju i optymalnego funkcjonowania), bowiem twórczość codzienna prawdopodobnie kojarzy się pozytywnie z byciem skutecznym, realizowaniem celów zawodowych i osobistych. W narracjach przywołane zostały głównie wydarzenia osobiste, w mniejszym stopniu globalne. Wśród tych pierwszych dominują wydarzenia związane z dzieciństwem, drogą edukacyjną, spotkanymi osobami, poszukiwaniem własnej drogi życiowej, kształtowaniem własnej indywidualności. Natomiast fakty globalne pojawiają się w przywołaniu wydarzeń związanych z: II wojną światową, okresem PRL-u, latami 80. XX w.

Narratorzy snuli opowieść o swoich działaniach twórczych, nie relacjonowali całego swojego życia, ale wybierali to, co uznawali za ważne dla tematyki wywiadu o twórczości codziennej. Prawdopodobnie inne dyspozycje badawcze mogłyby przyczynić się do konstruowania opowieści wokół innych tematów. Jednak wspólny dla różnych opowieści (,,małych i wielkich”) jest zapewne schemat dramaturgiczny, czyli schemat opowieści przedstawiającej bohatera/narratora, jego motywy działania i konsekwencje podejmowanych decyzji, doświadczanych trudności i pomocy podczas realizacji wytyczonych celów (Trzebiński, 2002; Straś-Romanowska, 2010; Świgulska, 2010).

Tabela 2

Dramaturgiczny schemat narracji a problemy badawcze

\begin{tabular}{|l|l|}
\hline \multicolumn{1}{|c|}{$\begin{array}{c}\text { Dramaturgiczny schemat narracji } \\
\text { autobiograficznych (por. Trzebiński, 2002) }\end{array}$} & \multicolumn{1}{c|}{ Szczegółowa problematyka badań } \\
\hline Bohater historii & Narrator (badany) \\
\hline $\begin{array}{l}\text { Motywy, wartości, intencje, cele, umiejętności } \\
\text { bohatera historii }\end{array}$ & $\begin{array}{l}\text { W jaki sposób tworzą twórcy codzienni, jakie } \\
\text { procesy intelektualne, emocjonalne, motywa- } \\
\text { cyjne oraz behawioralne biorą udział w po- } \\
\text { wstawaniu nowego i wartościowego produktu? }\end{array}$ \\
\hline Sfery aktywności bohatera & $\begin{array}{l}\text { Jakie przejawy (wytwory) twórczości codzien- } \\
\text { nej występują u badanych? }\end{array}$ \\
\hline
\end{tabular}


Tab. 2 (cd.)

\begin{tabular}{|l|l|}
\hline \multicolumn{1}{|c|}{$\begin{array}{c}\text { Dramaturgiczny schemat narracji } \\
\text { autobiograficznych (por. Trzebiński, 2002) }\end{array}$} & \multicolumn{1}{c|}{ Szczegółowa problematyka badań } \\
\hline $\begin{array}{l}\text { Warunki i sposoby rozwiązywania problemów, } \\
\text { przezwyciężanie przeszód przez bohatera au- } \\
\text { tonarracji }\end{array}$ & $\begin{array}{l}\text { Jakie czynniki wpływają na podejmowanie } \\
\text { twórczości codziennej oraz jej kontynuowanie? }\end{array}$ \\
\hline Komplikacje, które napotyka bohater & $\begin{array}{l}\text { Jakie czynniki wpływają na zaprzestanie twór- } \\
\text { czości codziennej? }\end{array}$ \\
\hline Indywidualna przestrzeń życia bohatera & $\begin{array}{l}\text { Cojest wyjątkowego, unikatowego w ich biogra- } \\
\text { fii twórczej?/Jaka jest cecha znacząca ich życia? }\end{array}$ \\
\hline
\end{tabular}

Źródło: Trzebiński (2002) oraz badania własne.

Podsumowując, warto pokreślić pedagogiczny aspekt narracji autobiograficznych, bowiem, jak pisze P. Oleś (2009, s. 380): „Opowiadanie lub opisywanie własnych doświadczeń, sprzyjające ich organizowaniu i rozumieniu, to nie tylko sposób na odreagowanie lub przepracowanie kłopotliwych emocji, ale także okazja do stawiania egzystencjalnych pytań, klasyfikowania wartości osobistych, formułowania celów, precyzowania dążeń i świadomego doboru sposobów postępowania". Na podstawie badań własnych, literatury z zakresu psychologii i pedagogiki twórczości oraz badań narracyjno-biograficznych proponuję autorskie zajęcia/ warsztat kompetencji autobiograficznych. W warstwie teoretycznej odwołuję się do narracyjnego sposobu rozumienia zdarzeń i własnego życia (Trzebiński, 2002; Tokarska, 2002), myśli Paula Ricoeura (2003), że samorozwój przybiera formę narracji, dzięki której potrafimy opowiadać własne życie poprzez zakorzenienie opowieści w tekstach kultury oraz do przekonania, że człowiek jest zdolny do autokreacji i przekształcania zastanych sytuacji życiowych w myśl egzystencjalnej filozofii człowieka (Bogusławski, 2005, 2008). Natomiast w warstwie praktycznej odwołuję się do pozyskanych danych empirycznych z wywiadów narracyjnych dotyczących twórczości codziennej, do metodycznych postulatów pedagogiki twórczości oraz koncepcji warsztatów przyszłości (Dubas, 1997). Odwołuję się także do własnego doświadczenia wyniesionego z zajęć o charakterze warsztatowym, prowadzonych dla studentów pedagogiki - Metody animacji grupy, jak również do warsztatów prowadzonych ze studentami edukacji dorosłych/andragogiki w trakcie przedmiotu - Warsztat kompetencji autobiograficznych. Cele zajęć są następujące:

- uczenie się postrzegania siebie jako człowieka rozwijającego się w ciągu życia i w konkretnych sytuacjach społeczno-historycznych, „wędrowca” żyjącego w świecie i wchodzącego z nim w interakcje;

- dostrzeżenie wielowątkowości życia naszego i innych ludzi, a tym samym zróżnicowanego odbioru świata; 
- wzmacnianie nastawienia zadaniowego, zwłaszcza w odniesieniu do przeszkód, problemów, sytuacji losowych;

- pozytywne reinterpretowanie własnego życia, ukazanie możliwości jego kreowania ${ }^{10}$.

Jakie będą efekty tych warsztatów dla zwiększenia dobrostanu życiowego ich uczestników, przekonamy się już wkrótce.

\section{Literatura}

Ai-Girl T., Lai-Chong L. (2004), Creativity for teachers, Marshall Cavendish Academic, Singapore. Boden M. A. (2010), Creativity and Art. Three roads to surprise, Oxford University Press, Oxford. Bogunia-Borowska M. (2009), Codzienność i społeczne konteksty życia, [w:] Barwy codzienności. Analiza socjologiczna, M. Bogunia-Borowska (red.), Wydawnictwo Naukowe Scholar, Warszawa.

Bogusławski M. M. (2005), Egzystencjalizm Sartre’a a tomizm egzystencjalny, „Przegląd Filozoficzny", $\mathrm{nr} 4$.

Bogusławski M. M. (2008), Podmiot u Sartre'a i Canguilhema. Notatki, „Forum Oświatowe”, numer specjalny.

Bogusławski M. M. i Modrzejewska-Świgulska M. (2011), „Profesjonalny” i ,nieprofesjonalny” wymiar biografii - na przykładzie opowieści autobiograficznej Michała Głowińskiego. Refleksja rozpisana na dwa glosy, [w:] Biografie naukowe. Perspektywa transdyscyplinarna, M. Kafar (red.), Wydawnictwo Uniwersytetu Łódzkiego, Łódź.

Brach-Czaina J. (1984), Etos nowej sztuki, Państwowy Instytut Wydawniczy, Warszawa.

Brach-Czaina J. (1999), Szczeliny istnienia, Wydawnictwo eFKa, Kraków.

Brian D. (1997), Einstein, Wydawnictwo AMBER, Warszawa.

Carr A. (2009), Psychologia pozytywna. Nauka o szczęściu i ludzkich siłach, Wydawnictwo Zysk i S-ka Poznań.

Cézanne P. (1968), Listy. Zebrat, opracowat, wstęem i komentarzem opatrzyt John Rewald, Państwowy Instytut Wydawniczy, Warszawa.

Cohn-Benedict C. (2008), Nieuchwytne dziedzictwo roku 1968. Wstep do wydania polskiego, [w:] Maj '68. Rewolta, D. Cohn-Bendit, R. Dammann (red.), Wydawnictwo Krytyki Politycznej Warszawa.

Craft A. (2000), Creativity across the primary curriculum, Continuum, London-New York.

Craft A. (2001a), Little c creativity, [w:] Creativity in education, A. Craft, B. Jeffrey, M. Leibling (eds), Continuum, London-New York.

Craft A. (2001b), Creativity and early years education, Continuum, London-New York.

Craft A. (2010), Possibility thinking and wise creativity: Educational Futures in England, [w:] Nurturing Creativity in the classroom, R. A. Beghetto, J. C. Kaufman (eds), Cambridge University Press, New York.

Cudowska A. (2004a), Kształtowanie twórczych orientacji życiowych w procesie edukacji, Wydawnictwo Trans Humana, Białystok.

Cudowska A. (2004b), Poczucie bezpieczeństwa personalnego w narracji o kreatywności, [w:] Edukacja dla bezpieczeństwa. Wybrane perspektywy, D. Kowalski, M. Kwiatkowski, A. Zduniak (red.),Wydawnictwo O’CHIKARA, Lublin-Poznań.

${ }^{10}$ Tutaj podziękowania kieruję do dr U. Tokarskiej, która zechciała krytycznie odnieść się do zaproponowanego warsztatu, dzięki czemu mogłam na nowo przemyśleć formułę warsztatów. 
Czapiński J. (2004), Spotkanie dwóch tradycji: hedonizmu i eudajmonizmu, [w:] J. Czapiński, Psychologia pozytywna. Nauka o szczęściu, zdrowiu, sile i cnotach, Państwowe Wydawnictwo Naukowe, Warszawa.

Czartoryska U. (1973), Od pop-art do sztuki konceptualnej, Wydawnictwo Artystyczne i Filmowe, Warszawa.

Dubas E. (1997), Warsztaty przyszłości w naukach o wychowaniu, Oficyna Wydawnicza „Impuls”, Kraków.

Dudzikowa M. (1994), Kompetencje autokreacyjne - czy i jak sa możliwe do nabycia w toku studiów pedagogicznych?, [w:] Ewolucja tożsamości pedagogiki, H. Kwiatkowska (red.), Polskie Towarzystwo Pedagogiczne, Warszawa.

Eliade M., Rocquet C.-H. (1992), Próba Labiryntu. Rozmowy z Claude-Henri Rocquetem, Wydawnictwo Sen, Warszawa.

Gardner H. (1988), Creative lives and creative works: A synthetic scientific approach, [w:] The nature of creativity. Contemporary psychological perspectives, R. J. Sternberg (ed.), Cambridge University Press, Cambridge.

Garfinkel H. (1984), Racjonalne cechy działalności naukowej i potocznej, [w:] Kryzys i schizma. Antyscjentystyczne tendencje w socjologii wspótczesnej, E. Mokrzycki (wybór i wstęp), Państwowy Instytut Wydawniczy, Warszawa.

Głowiński M. (2010), Kręgi obcości. Opowieść autobiograficzna, Wydawnictwo Literackie, Kraków.

Golka M. (2009), Czy jeszcze istnieje nie-codzienność?, [w:] Barwy codzienności. Analiza socjologiczna, M. Bogunia-Borowska (red.),Wydawnictwo Naukowe Scholar, Warszawa.

Gruber H. E. (1989), The evolving systems approach to creativity work, [w:] Creative people at work, H. E. Gruber, D. B. Wallace (eds), Oxford University Press, New York.

Heinich N. (2010), Socjologia sztuki, Oficyna Naukowa, Warszawa.

Hołówka T. (1986), Myślenie potoczne. Heterogeniczność zdrowego rozsądku, Państwowy Instytut Wydawniczy, Warszawa.

Jankowski D. (2000), Autoedukacja wyzwaniem współczesności, Wydawnictwo Adam Marszałek, Toruń.

Jawłowska A. (1988), Więcej niż teatr, Państwowy Instytut Wydawniczy, Warszawa.

Kizewich G. (2004), Principles of survival, a theory of every day creativity, Post, Alexandria, Washington.

Kozielecki J. (2002), Transgresja i kultura, Wydawnictwo Akademickie „Żak”, Warszawa.

Kubiak A. E. (2005), Jednak New Age, Jacek Santorski \& Co Agencja Wydawnicza, Warszawa.

Kubicka D. (2005), Strategie i techniki badań twórczości, [w:] W poszukiwaniu zastosowań psychologii twórczości, A. Tokarz (red.), Wydawnictwo Uniwersytetu Jagiellońskiego, Kraków.

Kvale S. (2004), Interview. Wprowadzenie do jakościowego wywiadu badawczego, Wydawnictwo Trans Humana, Białystok.

Lachowicz-Tabaczek K. (2004), Potoczne koncepcje świata i natury ludzkiej, Gdańskie Wydawnictwo Psychologiczne, Gdańsk.

Lalak D. (2010), Życie jako biografia. Podejście biograficzne w perspektywie pedagogicznej, Wydawnictwo Akademickie „Żak”, Warszawa.

Limont W. (2003), Twórczość w aspekcie cyklu życia, [w:] Twórczość - wyzwanie XXI wieku, E. Dombrowska, A. Niedźwiedzka (red.), Oficyna Wydawnicza „Impuls”, Kraków.

Maisel E. (2004), Everyday creative. 30 ways to wake up your inner artist, Red Wheel, Boston.

Martin F. (ed.), (2003), Everyday culture, Edward Arnold, London.

Maruszewski T. (1986), Mechanizmy tworzenia wiedzy potocznej, [w:] Człowiek i społeczeństwo, t. 2: Wiedza i jej problemy, J. Such (red.), Wydawnictwo Uniwersytetu Adama Mickiewicza, Poznań. 
Matuszewski R. (2008), Wisławy Szymborskiej dary przyjaźni i dowcipu, Oficyna Wydawnicza AURIGA, Warszawa.

Miles M. B., Huberman A. M. (2000), Analiza danych jakościowych, Wydawnictwo Trans Humana, Białystok.

Modrzejewska-Świgulska M. (2009), Badanie twórczości codziennej - perspektywa biograficzna, [w:] Metody pedagogicznych badań nad twórczością, K. J. Szmidt (red.), Wydawnictwo Akademii Humanistyczno-Ekonomicznej, Łódź.

Modrzejewska-Świgulska M. (2010), Twórczość codzienna pedagogów w perspektywie biograficznej, Łódź, niepublikowana praca doktorska.

Morawski S. (1985), Na zakręcie od sztuki do po-sztuki, Wydawnictwo Literackie, Kraków.

Morawski S. (2001), Wybór pism estetycznych, Wydawnictwo Universitas, Kraków.

Oleś P. K. (2008), Autonarracyjna aktywność człowieka, [w:] Narracja. Teoria i praktyka, B. Janusz, K. Gdowska, B. de Barbaro (red.), Wydawnictwo Uniwersytetu Jagiellońskiego, Kraków.

Oleś P. K. (2009), Wprowadzenie do psychologii osobowości, Wydawnictwo Naukowe Scholar, Warszawa.

Pachucki M. A., Lena J., Topper S. (2010), Creativity Narratives among college students: sociability and everyday creativity, „The Sociological Quarterly”, vol. 51.

Pietrasiński Z. (1990), Rozwój człowieka dorosłego, Wiedza Powszechna, Warszawa.

Richards R. (1900), Everyday creativity, eminent creativity, and health, „Creativity Research Journal", vol. 3.

Richards R. (1997), Conclusions: When illness yields creativity, [w:] Eminent creativity, everyday creativity and health, M. A. Runco, R. Richards (eds), Ablex Publishing Co., London.

Richards R. (1999), Everyday creativity, [w:] Encyclopedia of creativity, M. A. Runco, S. R. Pritzker (eds), vol. 1, Academic Press, London.

Richards R. (2007), Everyday creativity: Our hidden potential, [w:] Everyday creativity and new views of human nature. Psychological, social, and spiritual perspectives, R. Richards (ed.), American Psychological Association, Washington DC.

Richards R. (2010), Everyday creativity in the classroom: a trip trough time with seven suggestion, [w:] Nurturing Creativity in the classroom, R. A. Beghetto, J. C. Kaufman (eds), Cambridge University Press, New York.

Richards R., Kinney D. (1997), Mood swings and creativity, [w:] Eminent creativity, everyday creativity and health, R. Richards, M. A. Runco (eds), Ablex Publishing Co., London.

Richards R., Kinney D. K., Benet M., Merzel A. P. C. (1988), Assessing everyday creativity: Characteristic of the Lifetime Creativity Scales and validation with large samples, „Journal of Personality and Social Psychology", vol. 54, no. 3.

Richards R., Kinney D., Lunde I., Benet M., Merzel A. P. C. (1997), Creativity in manic-depressives, cyclothymes, their normal relatives, and control subjects, [w:] Eminent creativity, everyday creativity and health, R. Richards, M. A. Runco (eds), Ablex Publishing Co., London.

Rorty R. (2009), Przygodność, ironia i solidarność, Wydawnictwo W.A.B., Warszawa.

Runco M. A. (1996), Personal creativity: Definition and development issues, [w:] Creativity from childhood through adulthood: The development issues, M. Runco (ed.), Jossey-Bass Publ., San Francisco.

Runco M. A. (2005), Creativity giftedness, [w:] Conceptions of giftendness, R. J. Sternberg, J. Davidson (eds), Cambridge University Press, Cambridge.

Runco M. A. (2006), Reasoning and personal creativity, [w:] Creativity and reason in cognitive development, J. C. Kaufman, J. Bear (eds), Cambridge University Press, Cambridge.

Runco M. A. (2007), To understand is to create: An epistemological perspective on human nature and personal creativity, [w:] Everyday creativity and new views of human nature. Psychologi- 
cal, social, and spiritual perspectives, R. Richards (ed.), American Psychological Association, Washington DC.

Sawyer K. (2006), Explaining creativity. The science of human innovation, Oxford University Press, New York.

Seligman M. (2005), Prawdziwe szczęście, Wydawnictwo Media Rodzina, Poznań.

Schulz R. (1990), Twórczość - społeczne aspekty zjawiska, Państwowe Wydawnictwo Naukowe, Warszawa.

Shusterman R. (1998), Estetyka pragmatyczna: żywe piękno i refleksja nad sztuka, Wydawnictwo Uniwersytetu Wrocławskiego, Wrocław.

Stasiakiewicz M. (1999), Twórczość i interakcja, Wydawnictwo Uniwersytetu im. A. Mickiewicza, Poznań.

Straś-Romanowska M. (2010), Psychologia wobec matych $i$ wielkich narracji, [w:] Psychologia małych i wielkich narracji, M. Straś-Romanowska, B. Bartosz, M. Żurko (red.), Wydawnictwo ENETEIA, Warszawa.

Sulima R. (2000), Antropologia codzienności, Wydawnictwo Uniwersytetu Jagiellońskiego, Kraków.

Swann J., Maybin J. (2007), Introduction: Language creativity in Everyday, „Applied Linguistics”, vol. 28.

Szmidt K. J. (2001), Twórczość i pomoc w tworzeniu w perspektywie pedagogiki społecznej, Wydawnictwo Uniwersytetu Łódzkiego, Łódź.

Szmidt K. J. (2002), Wcześniej niż Fromm i Maslo, [w:] Korniłowicza i Radlińskiej koncepcje postawy twórczej na tle wspótczesnym, [w:] Nowe teorie twórczości. Nowe metody pomocy w tworzeniu, K. J. Szmidt, T. Piotrowski (red.), Oficyna Wydawnicza „Impuls”, Kraków.

Szmidt K. J. (2007), Pedagogika twórczości, Gdańskie Wydawnictwo Psychologiczne, Gdańsk.

Szmidt K. J. (w druku), Pedagogika twórczości, wyd. II zmienione i rozszerzone, Gdańskie Wydawnictwo Psychologiczne, Gdańsk.

Sztompka P. (2008), Życie codzienne - tematem najnowszej socjologii, [w:] Socjologia codzienności, P. Sztompka (red.), Wydawnictwo Znak, Kraków.

Sztompka P. (2009), Przestrzeń życia codziennego, [w:] Barwy codzienności. Analiza socjologiczna, M. Bogunia-Borowska (red.), Wydawnictwo Naukowe Scholar, Warszawa.

Świgulska M. (2007), Twórczość codzienna i możliwości jej empirycznego badania na przykładzie koncepcji R. Richards, „Przegląd Badań Edukacyjnych”, nr 1 (4).

Świgulska M. (2009), Twórczość w wymiarze egalitarnym - krytyczna prezentacja stanowisk, [w:] Psychologia twórczości. Nowe horyzonty, S. Popek, R. E. Bernecka, C. W. Domański, D. Turska, A. Zawadzka (red.), Wydawnictwo Uniwersytetu im. M. Curie-Skłodowskiej, Lublin.

Świgulska M. (2010), Momenty „,nadzwyczajnych spotkań”. Osoby znaczace w biografiach nauczycieli, [w:] Etyka i profesjonalizm w zawodzie nauczyciela, J. M. Michalak (red.), Wydawnictwo Uniwersytetu Łódzkiego, Łódź.

Tokarczuk O. (2007), Bieguni, Wydawnictwo Literackie, Kraków.

Tokarska U. (1999), W poszukiwaniu jedności i celu - wybrane techniki narracyjne, [w:] Wybrane zagadnienia z psychologii osobowości, A. Gałdowa (red.), Wydawnictwo Uniwersytetu Jagiellońskiego, Kraków.

Tokarska U. (2002), Narracja autobiograficzna w terapii i promocji zdrowia, [w:] Narracja jako sposób rozumienia świata, J. Trzebiński (red.), Gdańskie Wydawnictwo Psychologiczne, Gdańsk.

Tokarska U. (2010), Stawać się Panem Własnego Oblicza. O możliwościach intencjonalnych oddziaływań narracyjnych $w$ biegu życia, [w:] Psychologia matych $i$ wielkich narracji, M. Straś-Romanowska, B. Bartosz, M. Żurko (red.), Wydawnictwo ENETEIA, Warszawa.

Tokarz A. (2005), Dynamika procesu twórczego, Wydawnictwo Uniwersytetu Jagiellońskiego, Kraków.

Torrance E. P. (1995), Why fly? A philosophy of creativity, Ablex Publishing Corp. Norwood NJ. 
Trzebińska E. (2008), Psychologia pozytywna, Wydawnictwo Akademickie i Profesjonalne Warszawa. Trzebiński J. (2002), Narracyjne konstruowanie rzeczywistości, [w:] Narracja jako sposób rozumienia świata, J. Trzebiński (red.), Gdańskie Wydawnictwo Psychologiczne, Gdańsk.

Uszyńska-Jarmoc J. (2007), Od twórczości potencjalnej do autokreacji w szkole, Wydawnictwo Trans Humana, Białystok.

Yamaguchi J. (2005), 52 projects random acts of everyday creativity, Penguin Group, New York.

Zumthor P. (2010), Myślenie architekturą, Karakter, Kraków.

http://wyborcza.pl/1,91446,8959307,Wislawa_Szymborska_poetka_i_noblistka.http://www.teras-wish.com/whatisi.htm;

http://www.creativityandcognition09.org/; http://creativeeveryday.com/;

http://www.psychologytoday.com/articles/200910/everyday-creativity; http://eprints.qut.edu. au/5056/; http://applij.oxfordjournals.org/cgi/content/abstract/28/4/497;

http://shamurai.com/sites/creativity/papers/9.perkel.pdf; http://www.bellaonline.com/articles/ art15925.asp; http://wyborcza.pl/1,91446,8959307,Wislawa_Szymborska_poetka_i_noblistka.html\#ixzz1BUVv4BOv 